\title{
Maerl grounds provide both refuge and high growth potential for juvenile queen scallops (Aequipecten opercularis L.)
}

\section{Kamenos, NA}

http://hdl.handle.net/10026.1/1412

\begin{abstract}
10.1016/j.jembe.2004.08.007
Journal of Experimental Marine Biology and Ecology

Elsevier BV
\end{abstract}

All content in PEARL is protected by copyright law. Author manuscripts are made available in accordance with publisher policies. Please cite only the published version using the details provided on the item record or document. In the absence of an open licence (e.g. Creative Commons), permissions for further reuse of content should be sought from the publisher or author. 


\title{
Maerl grounds provide both refuge and high growth potential for juvenile queen scallops (Aequipecten opercularis L.)
}

\author{
Nicholas A. Kamenos ${ }^{\mathrm{a}, *}$, P. Geoffrey Moore ${ }^{\mathrm{a}}$, \\ Jason M. Hall-Spencer ${ }^{\mathrm{b}}$ \\ ${ }^{a}$ University Marine Biological Station Millport, Isle of Cumbrae KA28 OEG, Scotland, UK \\ ${ }^{\mathrm{b}}$ Marine Biology and Ecology Research Group, School of Biological Sciences, University of Plymouth, \\ Drake Circus, Plymouth PL4 8AA, England, UK
}

Received 16 March 2004; received in revised form 31 July 2004; accepted 11 August 2004

\begin{abstract}
Human damage to biogenic substrata such as maerl has been receiving increasing attention recently. Maerl forms highly biodiverse and heterogeneous habitats composed of loose-lying coralline red algae, which fulfil nursery area prerequisites for queen scallops (Aequipecten opercularis) and other invertebrates. The benefits obtained by queen scallops utilising maerl were poorly understood, so we used both laboratory predation and field tethering experiments to investigate the refuge and growth potential provided by pristine live maerl (PLM) grounds over other common substrata. In aquaria, more juvenile queen scallops ( $<35 \mathrm{~mm}$ shell height) survived on PLM than on gravel substrata in the presence of the crab Carcinus maenas or the starfish Asterias rubens. Field tethering experiments indicated similar survivorship of juvenile queen scallops on PLM and gravel; additionally, their growth rates were similar on both substrata. PLM allows scallops to seek refuge from predators and position themselves to optimise their food supply. Other bivalve refugia have been shown to provide poor food supply as a consequence of their high heterogeneity, yet maerl grounds provide a 'win-win' scallop nursery area coupling refuge availability with high food supply. (C) 2004 Elsevier B.V. All rights reserved.
\end{abstract}

Keywords: Growth; Maerl; Predation; 'Nursery area'; Refuge; Scallop; Scotland

* Corresponding author. Tel.: +44 1475 530581; fax: +44 1475530601.

E-mail address: nick.kamenos@millport.gla.ac.uk (N.A. Kamenos). 


\section{Introduction}

Fisheries science has paid increased attention to the impacts caused by demersal fishing and extraction gears, and it is now established that biogenic habitats (e.g., maerl, Hauton et al., 2003; corals, Hall-Spencer et al., 2002; seagrass beds, Moore and Jennings, 2000; kelp forests, Moore and Jennings, 2000; serpulid reefs, Moore et al., 1998) are particularly vulnerable to long-term mechanical damage. In the case of maerl habitats, towed demersal gears significantly reduce their heterogeneity to that of gravel substrata (Kamenos et al., 2003). Pristine live maerl (PLM) thalli are broken and subsequently die due to siltation (Hall-Spencer and Moore, 2000), leaving impacted dead maerl (IDM) grounds.

Maerl grounds (also known as 'rhodolith beds') (Foster, 2001) are composed of looselying, usually nongeniculated, coralline red algae (Giraud and Cabioch, 1976) and are found in areas characterised by high water movements (tidal and/or wave action) in the photic zone. Maerl grounds, which vary in size from tens to thousands of square metres, are dense accumulations of unattached coralline algae and occur throughout the world (Woelkerling, 1988; Foster, 2001). PLM grounds are highly biodiverse (BIOMAERL Team, 2003; Steller et al., 2003) and have significantly higher heterogeneity than common adjacent substrata including gravel, sand, and IDM (Kamenos et al., 2003). High heterogeneity equates to high biodiversity in many marine systems (Purvis and Hector, 2000; Tilman, 2000; Sala, 2001) with heterogeneous substrata providing prey with increased numbers of refuges from predators (Taylor, 1984; Arsenault and Himmelman, 1996; Lewis and Eby, 2002; Himmelman and Guay, 2003) and impairing certain predators' foraging regimes (Sponaugle and Lawton, 1990; Frandsen and Dolmer, 2002; Wong and Barbeau, 2003).

Seabed topography exerts a strong influence on the food supply to suspension-feeding bivalves, with increasing substratum roughness increasing turbulence above the sea bed (Mann and Lazier, 1996; Frandsen and Dolmer, 2002). Suspension feeders living within the cryptic habitats of structurally complex substrata gain protection from predators but tend to receive less food and grow more slowly than those living on, and in, less complex substrata (Bologna and Heck, 1999; Irlandi et al., 1999; Frandsen and Dolmer, 2002). Bologna (1998), for example, showed that scallops living on less complex substrata grew more quickly due to increased food supply, but overall scallop productivity was diminished due to increased predation.

The queen scallop Aequipecten opercularis is of commercial fisheries importance from the Mediterranean Sea north to the Faroe Islands (A.R. Brand, personal communication). Crabs and starfish are key predators of scallops worldwide (Pohle et al., 1991; Barbeau et al., 1994; Arsenault and Himmelman, 1996; Wong and Barbeau, 2003). Predation can be size-selective, e.g., adult Cancer irroratus crabs prefer larger scallops (Barbeau and Scheibling, 1994a) whereas Hyas araneus spider crabs and Asterias vulgaris starfish prefer small scallops (Barbeau and Scheibling, 1994a; Arsenault and Himmelman, 1996).

Nursery areas may be defined as habitats that are characterised by higher juvenile densities, survival, growth, and adult recruit provision than adjacent habitats (Beck et al., 2001). Maerl grounds have been found to fulfil the density and refuge prerequisites of a nursery area for queen scallops and other invertebrates and vertebrates (Kamenos et al., $2004 a, b)$. In the present study, we used a combination of field and laboratory observations 
to investigate if maerl grounds reduce predation and provide growth advantages to juvenile queen scallops. Such information is required to make informed choices concerning the fisheries benefits of protecting maerl habitats.

\section{Materials and methods}

\subsection{Laboratory predation experiment}

Rectangular experimental tanks ( $n=3$ ) (length $3 \mathrm{~m}$; width $0.89 \mathrm{~m}$; depth $0.45 \mathrm{~m}$ ) with semicirculating, coarsely filtered $(2 \mathrm{~mm})$ sea water were set up. Each tank had two $60 \times 89$ cm compartments separated using a 8 -mm diamond mesh (Netlon ${ }^{\circledR}$ ) that allows water circulation through each tank (Fig. 1). Water input and drainage were at each side of each tank. Water to the two experimental chambers in each tank was recirculated tank water, provided by a pump at a rate of $3000 \mathrm{l} \mathrm{h}^{-1}$ to ensure even and high water flow through each chamber. Tanks were covered with solid lids elevated $3 \mathrm{~cm}$ above the surface of the tanks to allow ambient daylight entry.

PLM thalli were collected using SCUBA from Caol Scotnish [Loch Sween, $56^{\circ} 01.99^{\prime} \mathrm{N}, 5^{\circ} 36.13^{\prime} \mathrm{W},-4$ to $-10 \mathrm{~m} \mathrm{CD}$ (chart datum)]. PLM thalli had a median rhodolith diameter of $43.3 \mathrm{~mm}$ and were assumed to be the upper extreme of heterogeneity of maerl locally. Gravel (median length $9.5 \mathrm{~mm}$; width $5.7 \mathrm{~mm}$ ) was collected from the MHWN at Ballochmartin Bay, Isle of Cumbrae $\left(55^{\circ} 47.09^{\prime} \mathrm{N}, 4^{\circ} 53.55^{\prime} \mathrm{W}\right)$. The collected substrata were not sorted to give results that were more representative of the natural environment. Live maerl was stored in a high-flow $\left(3000 \mathrm{l} \mathrm{h}^{-1}\right)$ outdoor seawater tank after collection until required; gravel was stored in low-flow $\left(1000 \mathrm{l} \mathrm{h}^{-1}\right)$ outdoor sea water tanks.

PLM and gravel were randomly placed in each compartment of each tank with substratum depth of $3 \mathrm{~cm}$ and left for 8 days to allow biofilm formation.

Juvenile $A$. opercularis were obtained from a commercial grower (Highland Aquaculture, Isle of Skye). The spat had been collected on spat bags and grown-on in lantern nets; thus, they were not preacclimated to any particular natural substratum.

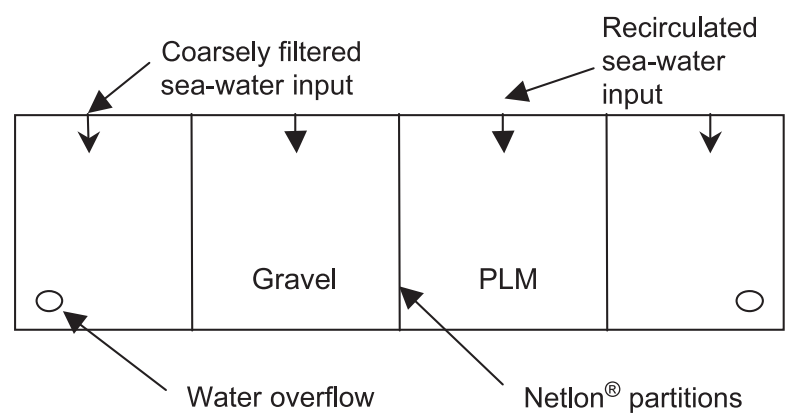

Fig. 1. Experimental tank setup used to compare juvenile $A$. opercularis predation by $A$. rubens and $C$. maenas on gravel and PLM. 
Fifty juvenile queen scallops were placed on each substratum. It was ensured that valve heights did not differ significantly between each substratum group within 2-18 $\mathrm{mm}$ shell height (SH) (umbo to margin) and 18-35 mm SH size classes. In control experiments, the numbers of live and dead scallops on each substratum and tank sides were noted at two 12- and 24-hourly intervals for 7 days. The extended observation period was required to allow determination of analysis time from subsequent predation treatments prior to complete predation of scallops due to the confined nature of the experiments. Experiments in the presence of a predator (Asterias rubens 13.9-14.2 $\mathrm{mm}$ total arm diameter; Carcinus maenas $63.2-65.1 \mathrm{~mm}$ carapce width, all male) were identical to the control; however, a predator was added to each substratum $24 \mathrm{~h}$ after the unacclimated scallop addition. Predators had been acclimated to the corresponding substrata in separate tanks for $24 \mathrm{~h}$ prior to the experimental period and had been fed to satiation $72 \mathrm{~h}$ before use. Each individual predator was used only once.

The coarsely filtered sea water was supplemented with 21 of concentrated mixed algal culture (Tetraselmis suecica, Chaetoceros ceratosporum, and Skeletonema costatum) on a daily basis.

\subsection{Field tethering experiment}

Fifty juvenile queen scallops $(2-18 \mathrm{~mm} \mathrm{SH})$, from the same source as the laboratory experiment, were assigned randomly to either PLM $(n=20)$, gravel $(n=20)$, or control $(n=10)$ groups. For each scallop, a small area on the upper valve near the umbo was cleaned using acetone and then dried using an air jet. One end of a $55-\mathrm{cm}$ monofilament nylon $(0.25 \mathrm{~mm}$ diameter $)$ tether was attached to the cleaned surface using cyanoacrylate adhesive (151 Super Glue ${ }^{\circledR}$ ). The other end of the tether was attached to a labelled 30-g teardrop weight. Prior tests indicated this weight was sufficient to prevent scallops from relocating. Shell heights of scallops in each group were compared to ensure there were no differences between the groups. Tethered scallops were stored in flow-through tanks until used 1 day after tether attachment.

The tethering experiments were carried out in the field at Caol Scotnish (Loch Sween) $56^{\circ} 01.99^{\prime} \mathrm{N} 05^{\circ} 36.13^{\prime} \mathrm{W}$ at $-7 \mathrm{~m} \mathrm{CD}$ (February). Two areas were chosen at random: one on PLM and the other on gravel. Using SCUBA, 20 tethered scallops were deployed on each site in a $4 \times 5$ array with $50 \mathrm{~cm}$ between scallops. Control scallops were placed in a modified crayfish creel (Trappy ${ }^{\circledR}$ creels), which prevented predator entry but allowed water flow through the creel. The control creel was fixed on an intermediate substratum of PLM and gravel.

Observations were made using SCUBA at $T_{+24} \mathrm{~h}$, noting whether each scallop was live, missing, or predated by a crab or starfish. Crab predation was assumed when either only one valve was left attached to the tether, or the remaining valve(s) was broken, while starfish predation was assumed when both valves remained unbroken and attached at the hinge. A similar experiment was carried out at the same sites using 18-35 mm SH queen scallops (June). Pilot experiments indicated $T_{+24 \mathrm{~h}}$ to be a suitable time to assess predation as, at longer time intervals, predation reduced numbers to extremely low levels as a consequence of tethering (Kamenos, personal observation). 


\subsection{Predator density quantification}

A. rubens and $C$. maenas densities on PLM and gravel ( $n=5$ for each month) were quantified in marked $10 \times 2-\mathrm{m}$ transects using SCUBA during both tethering experiments.

\subsection{Field growth experiment}

Logistical constraint prevented biomass determination in juvenile queen scallops using techniques such as those described by Bologna (1998). Change in SH was thus used as an estimator of growth rate. Shell heights of randomly selected free-living juvenile queen scallops $(n=36-316)$ on PLM and gravel substrata were measured with vernier callipers $( \pm 0.5 \mathrm{~mm})$ at two monthly intervals from December 2001 to February 2003 using SCUBA at Caol Scotnish. Sites on gravel and PLM substrata used for scallop collections were $>1000 \mathrm{~m}$ apart. Measured individuals were not returned.

\subsection{Data analysis}

\subsubsection{Laboratory predation experiment}

All laboratory study analyses were carried out on distributions 7-days postpredator addition. $T$ tests (assumptions met, arcsine-transformed) and Kruskal-Wallis tests were carried out on the proportion of live scallops found associated with each substratum. This measure was used as it is a proxy for both predated scallops and scallops that reattached to the sides of the experimental chamber during escape responses. In all cases, comparisons were with a Dunn-ŠSidák adjusted $p$ value for two comparisons.

\subsubsection{Field tethering experiments}

Mann-Whitney $U$ tests were used to compare numbers of live and predated scallops on each substratum for each size class. Frequencies of starfish and crab predated scallops on each substratum were compared using a G-test. The sizes of 'live,' 'starfish,' and 'crab-predated' scallops within and between substrata in each size class were compared using a two-way ANOVA (assumptions met) to account for the unique array of predators at each plot as experiments were run concurrently. Repeatedmeasures ANOVAs (assumptions met) were used to compare A. rubens and C. maenas densities on PLM and gravel during $<18 \mathrm{~mm} \mathrm{SH}$ (February) and 18-35 mm SH (June) trials.

\subsubsection{Field growth experiments}

Very few adults were present in the juvenile-dominated nursery areas, so only the initial (theoretically linear, if temporal period short) growth period of the von Bertalanffy growth function was represented; however, a strong seasonal effect was apparent, generating nonlinear growth over the experimental period-these factors prevented the use of modal progression analysis. Cohort-1 PLM and gravel growth rates were 
compared over all months sampled using an ANCOVA (assumptions met). Cohort-2 PLM and gravel growth rates were tested using Scheirer-Ray-Hare test comparing scallop sizes in October 2002 and February 2003 on each substratum only.

\section{Results}

\subsection{Laboratory predation experiment}

All scallops on PLM, gravel, and the sides of the experimental chambers were byssally attached. In both size class control treatments, there were no dead scallops; thus, it can be assumed that deaths in the predator-present treatments were not due to natural mortality but predation. All comparisons were at a Dunn-Šidák adjusted $p$ value of 0.025 .

\subsubsection{Less than $18 \mathrm{~mm} \mathrm{SH}$}

Significantly more live scallops were present on PLM than gravel at the end of the predation period in the $A$. rubens $\left(T_{4}=-17.15, p<0.001\right)$ but not $C$. maenas $\left(H_{1}=4.35\right.$, $p=0.037$ ) treatments (Fig. 2).

\subsection{2. $18-35 \mathrm{~mm} \mathrm{SH}$}

Significantly more live scallops were present on PLM than gravel at the end of the predation period in both $A$. rubens $\left(T_{3}=-7.15, p=0.006\right)$ and $C$. maenas $\left(T_{2}=-6.12\right.$, $p=0.023$ ) treatments (Fig. 2).

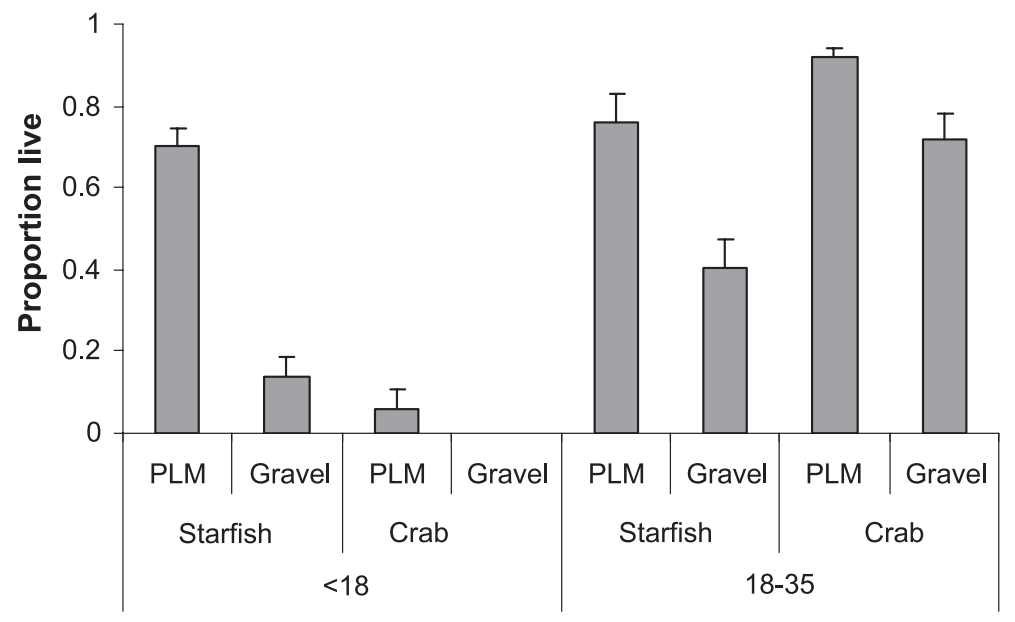

Size Class / Treatment / Substratum

Fig. 2. Mean $(n=3)$ numbers of $<18 \mathrm{~mm}(<18)$ and $18-35 \mathrm{~mm}(18-35)$ shell height queen scallops $(A$. opercularis) observed live on PLM and gravel in A. rubens (starfish) and C. maenas (crab) present treatments on day 7 . Error bars $=95 \%$ CI. 


\subsubsection{PLM}

There was no significant difference $\left(T_{3}=-1.44, p=0.245\right)$ in the numbers of live $<18$ $\mathrm{mm} \mathrm{SH}$ and $18-35 \mathrm{~mm} \mathrm{SH}$ scallops in $A$. rubens treatments. There was a significantly $\left(T_{2}=-33.31, p=0.001\right)$ greater numbers of live $18-35 \mathrm{~mm} \mathrm{SH}$ than $<18 \mathrm{~mm} \mathrm{SH}$ scallops in the C. maenas treatments (Fig. 2).

\subsubsection{Gravel}

There was a significantly $\left(T_{3}=-6.32, p=0.008\right)$ greater numbers of live $18-35 \mathrm{~mm} \mathrm{SH}$ than $<18 \mathrm{~mm}$ SH scallops in the $A$. rubens treatments. There was no significant difference $\left(H_{1}=4.35, p=0.037\right)$ in the number of live $<18 \mathrm{~mm} \mathrm{SH}$ and $18-35 \mathrm{~mm}$ SH scallops in $C$. maenas treatments (Fig. 2).

\subsection{Field tethering experiment}

\subsubsection{Surviving scallop densities and frequencies}

For both size classes, all control scallops were alive at the end of the experimental period; thus, any deaths in the treatment groups were attributed to predation or escape (Table 1). There was no significant difference in the numbers of live and predated scallops on PLM and gravel in $<18 \mathrm{~mm} \mathrm{SH}$ queen scallops at $T_{24 \mathrm{~h}}$ $\left(W_{1}=442, p=0.303\right)$ as well as $18-35 \mathrm{~mm} \mathrm{SH}$ queen scallops at $T_{24 \mathrm{~h}}\left(W_{1}=339\right.$, $p=0.836$ ).

Within the 'predated scallop' term referred to above, frequency analysis of 'crabpredated' 'starfish-predated' juvenile queen scallops on PLM and gravel indicated distributions to be independent of substratum for $<18 \mathrm{~mm}$ juvenile queen scallops at $T_{24} \mathrm{~h}$ $\left(G_{1}^{\prime}=1.07, p>0.05\right)$ as well as $18-35 \mathrm{~mm} \mathrm{SH}$ scallops at $T_{24 \mathrm{~h}}\left(G_{1}^{\prime}=0.34, p>0.05\right)$.

\subsubsection{Predator densities}

Significantly higher $\left(F_{1}=21.08, p=0.002\right)$ densities of $A$. rubens were present on PLM than gravel (Fig. 3). Densities were significantly higher $\left(F_{1}=9.09, p=0.017\right)$ in June than February. Interaction was nonsignificant $\left(F_{1}=4.38, p=0.07\right)$. Equal densities of $C$. maenas were present on both substrata $\left(F_{1}=0.30, p=0.599\right)$ (Fig. 3). Densities were significantly higher $\left(F_{1}=9.36, p=0.015\right)$ during June. Interaction was nonsignificant $\left(F_{1}=2.70, p=0.139\right)$.

Table 1

Numbers of live, crab-predated (crab), starfish-predated (starfish), and missing juvenile $A$. opercularis in $<18 \mathrm{~mm}$ $\mathrm{SH}(<18)$ and $18-35 \mathrm{~mm} \mathrm{SH}(18-35)$ groups at $T_{+24} \mathrm{~h}$ tethered in Caol Scotnish

\begin{tabular}{lllcll}
\hline Size group & Treatment & Live & Crab & Starfish & Missing \\
\hline$<18$ & PLM & 15 & 2 & 3 & 0 \\
& Gravel & 12 & 4 & 4 & 0 \\
\multirow{3}{*}{$18-35$} & Control & 10 & 0 & 0 & 0 \\
& PLM & 6 & 11 & 1 & 1 \\
& Gravel & 6 & 12 & 0 & 2 \\
& Control & 10 & 0 & 0 & 0 \\
\hline
\end{tabular}




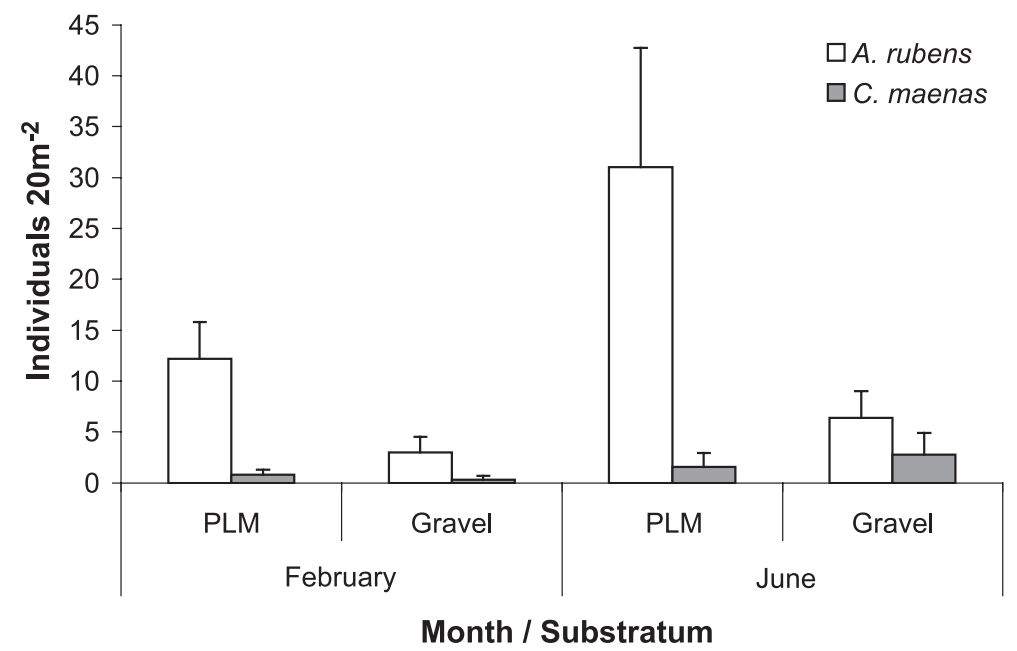

Fig. 3. Mean $(n=5) A$. rubens and C. maenas densities on PLM and gravel at Caol Scotnish in February and June. Error bars $=95 \% \mathrm{CI}$.

\subsubsection{Size of predated scallops}

There were no significant differences in the sizes of live, crab, and starfish-predated scallops on PLM and gravel in $<18 \mathrm{~mm}\left(F_{4}=1.04, p=0.401\right)$ or $18-35 \mathrm{~mm}\left(F_{2}=0.18\right.$, $p=0.835$ ) SH groups (Fig. 4) (only one scallop was predated by $A$. rubens in the 18-35 $\mathrm{mm} \mathrm{SH}$ group and was not included in the analysis).

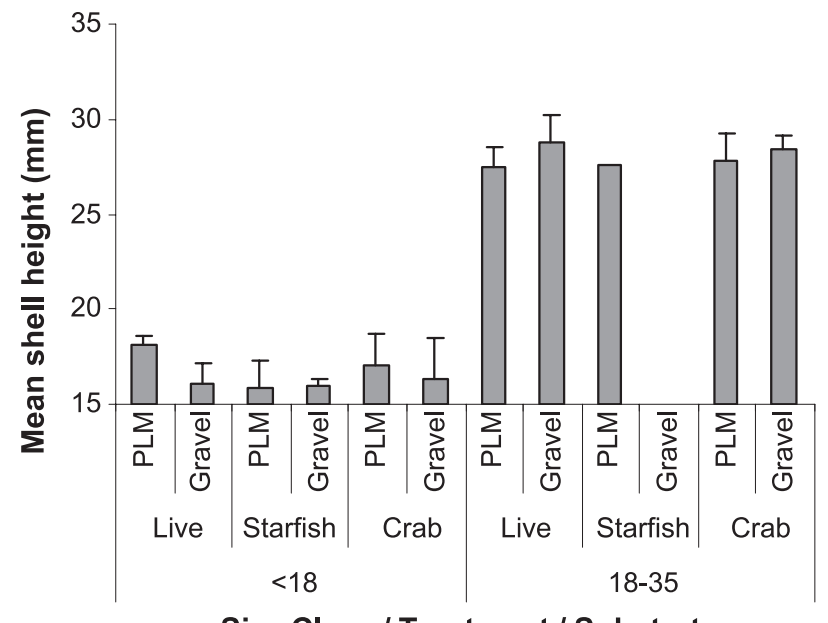

\section{Size Class / Treatment / Substratum}

Fig. 4. Mean $(n=3-12)$ shell heights of $<18 \mathrm{~mm}(<18)$ and 18-35 mm shell height (18-35) live, C. maenas (crab)predated and $A$. rubens (starfish)-predated juvenile queen scallops on PLM and gravel. Only one scallop was starfish-predated in the PLM 18-35 mm group and none in the gravel $18-35 \mathrm{~mm}$ group. Error bars $=95 \%$ CI. 


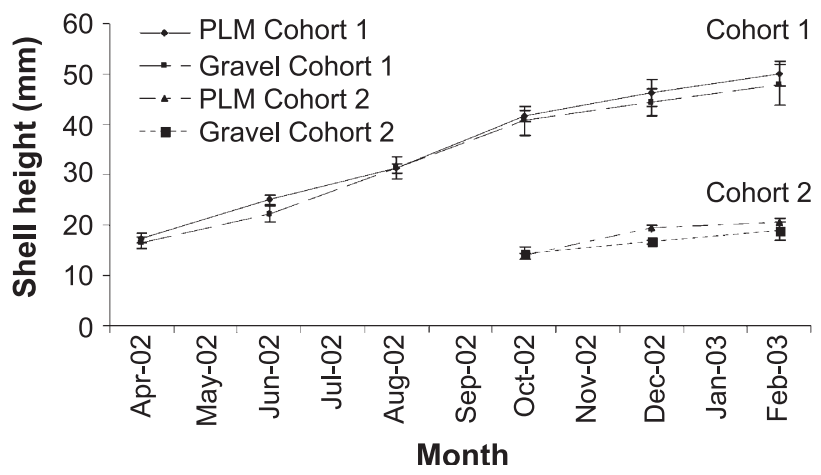

Fig. 5. Shell height of $A$. opercularis on PLM and gravel at Caol Scotnish during two monthly surveys between April 2002-February $2003(n=36-316)$. Error bars=95\% CI; lines join mean shell height within each cohort.

\subsection{Field growth experiment}

Spawning and settlement dates of juveniles represented in cohorts 1 and 2 (Fig. 5) were not known; thus, data analyses were done individually on each cohort. Nonsignificant ANCOVA interaction $\left(F_{1}=0.02, p=0.891\right)$ indicated no significant difference in growth rates of cohort 1 juvenile queen scallops on PLM and gravel over a 10-month period (April 2002-February 2003) for 10-57 mm SH queen scallops. Nonsignificant Scheirer-RayHare interaction $\left(H_{1}=1.69, p=0.193\right)$ indicated nonsignificant difference in growth rates of cohort 2 juvenile queen scallops on PLM and gravel over a 4-month period (October 2002-February 2003) for 7-32 mm SH juvenile queen scallops. In cohort 1, scallop growth rates from April to September were higher on both PLM (4.1 mm month ${ }^{-1}$ ) and gravel (4.1) than rates from October to February (PLM=1.7, gravel=0.89). Cohort 2 growth rates during October to February were comparable to cohort 1 rates (PLM=1.32, gravel $=0.89$ ).

\section{Discussion}

Juvenile A. opercularis $(<35 \mathrm{~mm} \mathrm{SH})$ mortality rates were affected by a combination of predator species, habitat availability, and scallop size. In laboratory experiments, scallop survival rates on PLM were generally higher than those on gravel, which is characterised by lower structural heterogeneity. A. opercularis joins a growing list of scallops (e.g., Argopecten irradians, Pohle et al., 1991; Garcia-Esquivel and Bricelj, 1993; Arnold et al., 1998; Irlandi et al., 1999; Chlamys islandica, Arsenault and Himmelman, 1996; Himmelman and Guay, 2003; and Placopecten magellanicus, Wong and Barbeau, 2003) and other bivalves (e.g., Geukensia demissa, Lee and Kneib, 1994; Mercenaria mercenaria, Arnold, 1984; Mya arenaria, Lipcius and Hines, 1986; and Mytilus edulis, Frandsen and Dolmer, 2002), which are known to benefit from the protection afforded by structurally complex substrata. 


\subsection{A. opercularis behaviour}

Both size-classes of queen scallops survived better in maerl through refuge use and reduced predator efficiency associated with increasing complexities of substrata. In aquaria, A. rubens was more efficient at predating $<18 \mathrm{~mm} \mathrm{SH}$ than $18-35 \mathrm{~mm} \mathrm{SH}$ A. opercularis on gravel, whilst there was no change in predation rates between the two size classes on PLM. The larger juveniles were better able to swim and escape the starfish, whilst the smaller juveniles sought refuge using intramatrix and intermatrix spaces within the maerl. Once located by predators, the juvenile queen scallops using PLM refugia would gape, gripping the surrounding matrix and making extraction from the maerl both time-consuming and difficult.

Absence of statistical significance in comparison with the $<18 \mathrm{~mm}$ SH scallops on gravel in the crab treatment may be attributed to an artefact of the enclosed experimental design leading to high predation rates and complete sample predation. Although this causes analysis problems, biologically, the result is important as there were survivors present on the comparative substrata.

Structurally complex substrata are important for scallop species that hide from predators (Wong and Barbeau, 2003), such as juvenile $C$. islandica, which nestle in crevices and under shells (Arsenault and Himmelman, 1996; Himmelman and Guay, 2003), and A. irradians, which attach to eelgrass (Pohle et al., 1991; Arnold et al., 1998; Irlandi et al., 1999). Our findings for A. opercularis are similar to those of Wong and Barbeau (2003), who showed that small $P$. magellanicus juveniles sought substratum refuges whereas the larger juveniles escaped using their more effective swimming abilities.

\subsection{Predator behaviour}

C. maenas ate fewer small $(<18 \mathrm{~mm} \mathrm{SH})$ and large $(18-35 \mathrm{~mm} \mathrm{SH})$ juvenile queen scallops on the highly complex PLM than on gravel in laboratory experiments. Sponaugle and Lawton (1990) also observed that crabs (Ovalipes ocellatus and Callinectes sapidus) feeding on juvenile $M$. mercenaria bivalves were much more successful on sand than on more complex substrata such as sand/gravel and sand/shell. Similarly, C. maenas spent significantly more time locating mussels on more complex substrata, explaining reduced predation mortality on complex substrata (Frandsen and Dolmer, 2002). However, Wong and Barbeau (2003) observed no effect of substratum type on predation rates of C. irroratus on $P$. magellanicus, but did find that on more heterogeneous substrata, crabs picked up many prey-like objects in an nondiscriminatory manner then rejected nonprey items.

Apart from the effects of change in escape responses of growing juvenile queen scallops, discussed above, this and other studies (Wong and Barbeau, 2003) have observed starfish predation to be less effective on more complex substrata, possibly because starfish have to spend more time searching for prey and extracting them from complex substrata (Wong and Barbeau, 2003).

\subsection{Tethering}

Confinement of scallops during predation experiments is often achieved using tethering, although this interferes with their ability to escape. Barbeau and Scheibling 
(1994b) and Barbeau et al. (1994) showed that whilst C. irroratus ate similar amounts of tethered and untethered scallops (P. magellanicus), A. vulgaris was able to consume significantly more tethered scallops. In crab-scallop interactions, encounter rate was the major determinant of predation rate, whereas with starfish, the probability of capture upon encounter was the major determinant of predation rate because scallops readily escaped from starfish by swimming or jumping.

Although no differences in mortality rates were observed in our tethering experiments between scallops on PLM and gravel, two factors indicate tethered scallops on PLM to have been more successful than those on gravel: (1) significantly more A. rubens were present on PLM than gravel, with its close relative A. vulgaris able to consume 16.7 times more tethered scallops than free scallops (Barbeau et al., 1994); and (2) although $55 \mathrm{~cm}$ of tether was initially available to the scallops, this was severely reduced on PLM due to tangling with the maerl matrix - tangling did not occur on gravel. The latter is a known artefact of tethering experiments (Aronson and Heck, 1995), leading to disproportionately increased relative mortality in habitats causing reduction in tether length. Thus, it is feasible to assume that nontethered scallops associated with PLM would have lower mortality rates than scallops on the less complex gravel.

\subsection{Growth}

Bay scallops (A. irradians) have been observed to have higher growth rates along the margins of seagrass patches than within patches (Bologna and Heck, 1999; Irlandi et al., 1999) and it was suggested that food supply was the primary factor controlling these differences in growth, with restricted flow within seagrass meadows equating to lower food supply (Irlandi et al., 1999). Similarly, we expected lower growth rates for scallops utilising higher complexity PLM beds than those on nearby gravel substrata. However, we observed similar growth rates between scallops on gravel and PLM.

The absence of the expected growth differentiation between scallops on PLM and gravel may be due to: (1) the presence of refuges provided by PLM (Kamenos et al., 2004a) and lower-than-expected growth rates on gravel due to the increased energetic costs of predator/prey interactions in habitats offering few refuges (Gilliam, 1987); and (2) the considerable motility of juvenile queen scallops allowing them to use refuges in predator presence yet reattach to PLM surface in the absence of predators (Kamenos et al., 2004a) and thereby make use of the higher food supply in areas with increased flow.

Seasonal effects on growth rates observed on PLM and gravel were comparable to growth rates and seasonal effects observed during warmer and colder months in other studies (Paul, 1981; Richardson et al., 1982).

\section{Conclusions}

We have shown that PLM is an unusual substratum allowing scallops to maintain potential growth rates equal to those of scallops on less heterogeneous substrata. PLM 
grounds have been shown to function widely as nursery areas in western Scottish waters (Kamenos et al., 2004b) and we now have some insight into refuge and growth process occurring within this important habitat. PLM has also been shown to have significantly higher heterogeneity than, and be more attractive to, juvenile queen scallops than IDM (Kamenos et al., 2003; 2004a). Alteration of PLM to IDM thus reduces the refuge potential of the substratum and may thus alter growth-predation relationships to that of less heterogeneous substrata. It is therefore likely that continued widespread destruction of PLM grounds (BIOMAERL Team, 2003) will adversely affect local populations of queen scallops by reducing refuge availability, degrading of nursery areas, and, thus, eventually reducing or stopping recruitment to adult populations of queen scallops.

\section{Acknowledgments}

The Scottish Natural Heritage contributed to funding this work. N.A.K. was in receipt of a Sheina Marshall studentship from the University Marine Biological Station Millport. J.H.-S. was in receipt of a Royal Society University Research Fellowship. Thanks also to Kenny Cameron, Stephen Muir, Philip Smith, the crews of the RV Aplysia and RV Aora, and unnamed reviewers. [RW]

\section{References}

Arnold, W.S., 1984. The effects of prey size, predator size, and sediment composition on the rate of predation of the blue crab, Callinectes sapidus Rathbun, on the hard clam, Mercenaria mercenaria (Linne). J. Exp. Mar. Biol. Ecol. 80, 207-219.

Arnold, W.S., Marelli, D.C., Bray, C.P., Harrison, M.M., 1998. Recruitment of bay scallops Argopecten irradians in the Floridan Gulf of Mexico waters: scales of coherence. Mar. Ecol., Prog. Ser. 170, 143-157.

Aronson, R.B., Heck, K.L., 1995. Tethering experiments and hypothesis-testing in ecology. Mar. Ecol., Prog. Ser. 121, 307-309.

Arsenault, D.J., Himmelman, J.H., 1996. Size-related changes in vulnerability to predators and spatial refuge use by juvenile Iceland scallops Chlamys islandica. Mar. Ecol., Prog. Ser. 140, 115-122.

Barbeau, M.A., Scheibling, R.E., 1994a. Behavioral mechanisms of prey size selection by sea stars (Asterias vulgaris Verrill) and crabs (Cancer irroratus Say) preying on juvenile sea scallops (Placopecten magellanicus Gmelin). J. Exp. Mar. Biol. Ecol. 180, 103-136.

Barbeau, M.A., Scheibling, R.E., 1994b. Procedural effects of prey tethering experiments: predation of juvenile scallops by crabs and seastars. Mar. Ecol., Prog. Ser. 111, 305-310.

Barbeau, M.A., Scheibling, R.E., Hatcher, B.G., Taylor, L.H., Hennigar, A.W., 1994. Survival analysis of tethered juvenile sea scallops Placopecten magellanicus in field experiments: effects of predators, scallop size and density, site and season. Mar. Ecol., Prog. Ser. 115, 243-256.

Beck, M.W., Heck, K.L., Able, K.W., Childers, D.L., Eggleston, D.B., Gillanders, B.M., Halpern, B., Hays, C.G., Hoshino, K., Minello, T.J., Orth, R.J., Sheridan, P.F., Weinstein, M.R., 2001. The identification, conservation, and management of estuarine and marine nurseries for fish and invertebrates. BioScience 51, $633-641$.

BIOMAERL Team, 2003. Conservation and management of northeast Atlantic and Mediterranean maerl beds. Aquat. Conserv. Mar. Freshw. Ecosyst. 13, 565-576.

Bologna, P.A.X., 1998. Growth, production, and reproduction in bay scallops Argopecten irradians concentricus (Say) from the northern Gulf of Mexico. J. Shellfish Res. 17, 911-917. 
Bologna, P.A.X., Heck, K.L., 1999. Differential predation and growth rates of bay scallops within seagrass habitat. J. Exp. Mar. Biol. Ecol. 239, 299-314.

Foster, M.S., 2001. Rhodoliths: between rocks and soft places. J. Phycol. 37, 659-667.

Frandsen, R.P., Dolmer, P., 2002. Effects of substrate type on growth and mortality of blue mussels (Mytilus edulis) exposed to the predator Carcinus maenas. Mar. Biol. 141, 253-262.

Garcia-Esquivel, Z., Bricelj, V.M., 1993. Ontogenic changes in microhabitat distribution of juvenile bay scallops, Argopecten irradians irradians (L.), in eelgrass beds, and their potential significance to early recruitment. Biol. Bull. 185, 42-55.

Gilliam, J.F., 1987. Habitat selection under predation hazard: test of a model with foraging minnows. Ecology 68 , $1856-1862$.

Giraud, G., Cabioch, J., 1976. Ultrastructural study of the activity of superficial cells of the thallus of the Corallinaceae (Rhodophyceae). Phycologia 13, 405-414.

Hall-Spencer, J.M., Moore, P.G., 2000. Impact of scallop dredging on maerl grounds. In: Kaiser, M.J., de Groot, S.J. (Eds.), Effects of Fishing on Non-Target Species and Habitats: Biological, Conservation and SocioEconomic Issues. Blackwell, Oxford, pp. 105-117.

Hall-Spencer, J.M., Allain, V., Fossa, J.H., 2002. Trawling damage to Northeast Atlantic ancient coral reefs. Proc. R. Soc. Lond., B 269, 507-511.

Hauton, C., Hall-Spencer, J.M., Moore, P.G., 2003. An experimental study of the ecological impacts of hydraulic bivalve dredging on maerl. ICES J. Mar. Sci. 60, 381-392.

Himmelman, J.H., Guay, M., 2003. Could adding scallop shells to the sea bottom increase the production of scallops and other commercially important species? Proceedings of the 14th International Pectinid Workshop, St. Petersburg, Florida., pp. 173-174.

Irlandi, E.A., Orlando, B.A., Ambrose, W.G., 1999. Influence of seagrass habitat patch size on growth and survival of juvenile bay scallops, Argopecten irradians concentricus (Say). J. Exp. Mar. Biol. Ecol. 235, $21-43$.

Kamenos, N.A., Moore, P.G., Hall-Spencer, J.M., 2003. Substratum heterogeneity of dredged vs. un-dredged maerl grounds. J. Mar. Biol. Assoc. U.K. 83, 411-413.

Kamenos, N.A., Moore, P.G., Hall-Spencer, J.M., 2004a. Attachment of the juvenile queen scallop (Aequipecten opercularis (L.)) to maerl in mesocosm conditions; juvenile habitat selection. J. Exp. Mar. Biol. Ecol. 306, $139-155$.

Kamenos, N.A., Moore, P.G., Hall-Spencer, J.M., 2004b. The nursery area function of maerl grounds for juvenile queen scallops (Aequipecten opercularis) and other invertebrates. Mar. Ecol., Prog. Ser. 247, 183-189.

Lee, S.Y., Kneib, R.T., 1994. Effects of biogenic structure on prey consumption by the xanthid crabs Eurytium limosum and Panopeus herbstii in a salt-marsh. Mar. Ecol., Prog. Ser. 104, 39-47.

Lewis, D.B., Eby, L.A., 2002. Spatially heterogeneous refugia and predation risk in intertidal salt marshes. Oikos 96, 119-129.

Lipcius, R.N., Hines, A.H., 1986. Variable functional-responses of a marine predator in dissimilar homogeneous microhabitats. Ecology 67, 1361-1371.

Mann, K.H., Lazier, J.R.N., 1996. Biology and boundary layers. Dynamics of Marine Ecosystems: Biological Physical Interactions in the Oceans. Blackwell, London, pp. 11-54.

Moore, P.G., Jennings, S., 2000. Commercial Fishing; the wider ecological impacts. Blackwell, London.

Moore, C.G., Saunders, G.R., Harries, D.B., 1998. The status and ecology of reefs of Serpula vermicularis L. (Polychaeta: Serpulidae) in Scotland. Aquat. Conserv. Mar. Freshw. Ecosyst. 8, 645-656.

Paul, J.D., 1981. Natural settlement and early growth of spat of the queen scallop Chlamys opercularis (L.), with reference to the formation of the first growth ring. J. Molluscan. Stud. 47, 53-58.

Pohle, D.G., Bricelj, V.M., Garcia-Esquivel, Z., 1991. The eelgrass canopy: an above-bottom refuge from benthic predators for juvenile bay scallops Argopecten irradians. Mar. Ecol., Prog. Ser. 74, 47-59.

Purvis, A., Hector, A., 2000. Getting the measure of biodiversity. Nature 405, 212-219.

Richardson, C.A., Taylor, A.C., Venn, T.J., 1982. Growth of the queen scallop Chlamys opercularis in suspended cages in the Firth of Clyde. J. Mar. Biol. Assoc. U.K. 62, 157-169.

Sala, E.O., 2001. Ecology: the price put on biodiversity. Nature 412, 34-36.

Sponaugle, S., Lawton, P., 1990. Portunid crab predation on juvenile hard clams: effect of substrate type and prey density. Mar. Ecol., Prog. Ser. 67, 43-53. 
Steller, D.L., Riosmena-Rodriguez, R., Foster, M.S., Roberts, C.A., 2003. Rhodolith bed diversity in the Gulf of California: the importance of rhodolith structure and consequences of disturbance. Aquat. Conserv. Mar. Freshw. Ecosyst. 13, S5-S20.

Taylor, R.J., 1984. Prey refugia. Predation. Chapman \& Hall, New York, pp. 69-81.

Tilman, D., 2000. Causes, consequences and ethics of biodiversity. Nature 405, 208-211.

Woelkerling, W.J., 1988. The Red Coralline Algae: An Analysis of the Genera and Subfamilies of Nongeniculate Corallinacea. Oxford University Press, New York.

Wong, M.C., Barbeau, M.A., 2003. Effects of substrate on interactions between juvenile sea scallops (Placopecten magellanicus Gmelin) and predatory sea stars (Asterias vulgaris Verrill) and rock crabs (Cancer irroratus Say). J. Exp. Mar. Biol. Ecol. 287, 155-178. 